\title{
Processing methods for feather meal and aspects of quality
}

\author{
A. F. B. VAN DER POEL \& A. R. EL BOUSHY \\ Department of Animal Nutrition, Wageningen Agricultural University, Haagsteeg 4, \\ NL 6708 PM Wageningen, Netherlands
}

Received 13 November 1989; accepted 18 June 1990

\begin{abstract}
Feather waste from slaughtering can be processed into feather meal (FM) by the application of heat to wet feathers. Conversion of poultry feathers to FM by thermal treatments involves physical alteration of feather protein (loss of molecular organization) and chemical changes. Principle chemical changes are loss of the amino acid cystine, appearance of the unusual amino acid lanthionine and increased susceptibility of protein to enzymatic hydrolysis. Thereby the in vivo digestibility of feather protein is increased and FM thus can be incorporated in diets for monogastic animals. This overview covers the processing equipment and the possible quality control parameters with respect to the thermal processing of feathers. The final quality of FM depends mainly on the time - pressure (temperature) pattern in the hydrolyzation stage of feathers, which is related to law requirements for sterilization. Some parameters for the final feather meal quality are discussed.
\end{abstract}

Keywords: rendering, feather meal, thermal processing, protein quality, digestibility

\section{Introduction}

The tremendous growth of the poultry industry results in a large amount of offal and waste. The wastes from slaughtering are mainly blood, feathers and offal (viscera, heads and feet) and can be collected separately and can subsequently be processed into separate protein meals like blood meal, FM and poultry meat-meal, respectively. They also can be processed into mixed poultry meal. If well processed, these offals can be incorporated into compound diets for livestock feeding and may replace to some extent expensive feed ingredients.

New industrialised ways of slaughtering and of poultry processing has intensified the problem of disposal of poultry waste which is sufficient to attract the rendering industry. This will play a role in solving protein needs and improving human environmental struggle in countries, where rendering plants are developing and animal proteins are not in abundant.

Poultry industries now exists in many countries and generate large amounts of offals. From these offals, feathers are a potential source of protein including the amino acid cystine, in particular. However, the protein in raw feathers, mainly kera- 
tin, is less than $20 \%$ digestible (Williams et al., 1979). Natural, the keratinous structure is resistant to digestive enzymes. This property can be attributed to the highly organized structure of keratin in which the cystine-disulfide bonds are mainly responsible (McCasland \& Richardson, 1966). Therefore, feathers are treated in rendering plants to transform them to valuable proteins.

Thermal processing enhances the FM digestibility in vivo (Papadopoulos et al., $1985 ; 1986$ ) and creates a germ-free product (Rasmussen et al., 1964).

In achieving feather keratin hydrolyzation, feathers can be steam-treated by the application of heat to wet feathers. It becomes thus important to study the processing of feathers and inherent protein digestibility after heat treatment. Subsequently, processing conditions and quality control parameters can be established to optimize feather meal protein quality for livestock consumption.

Some experiments have been reported on the nutritional evaluation of hydrolized FM (Morris \& Balloun, 1973; Papadopoulos, 1984). However, little is known about the actual processing and processing equipment.

This paper deals with aspects of processing equipment used in the thermal processing of feathers. The aim is to give a reference description of various systems and to gain a better understanding of the possible processing variables used in conventional industrial feather processing. All pressure parameters in this overview are expressed in kilopascal $(\mathrm{kPa})$ above atmospheric pressure. In this way, a pressure of $300 \mathrm{kPa}$ means an absolute pressure value of $400 \mathrm{kPa}$.

\section{Protein quality of feathers}

\section{Feather keratin denaturation}

Industry has developed processes for the conversion of waste material to a 'profitable product'. One of those processes includes the treatment of feathers in order to change or hydrolyze the protein into a more digestible state for the animal. The mean composition of FM the range for in vitro protein digestibility and a characterization of the keratinaceous protein are indicated in Table 1.

Feathers consist of keratin proteins which, in its native state, are very resistant to digestion by monogastric animals. Native keratin protein exists in large macromolecules of amino acids jointed together by peptide cross-links (primary chemical bonds). These molecular chains are arranged in a distinctive physical arrangement by secondary and tertiary bonds which have no true chemical nature. These are hydrogen bonds (between chains) or interconnections by peptide cross-links of amino acids in chains and to some extent between chains. Due to this high degree of polymerization, keratin protein in feed is resistant to digestive enzymes in the intestinal tract.

Hydrogen bonds between molecular chains and the peptide cross-links between amino acids, however, can be broken down by processing. The use of alkali treatment (Retrum, 1981) and enzymatic modifications (Papadopoulos, 1986) may be applied in establishing a change in the nutritional properties of this protein and especially the latter treatment needs further investigation. For modification of feather 
Table 1. Proximate analysis ( $\mathrm{g} \mathrm{kg}^{-1}$; as fed) of feather meal and protein digestibility after hydrolyzation and final drying.

\begin{tabular}{lllllll}
\hline Feather meal after & Dry matter & Ash & Crude protein & Crude fat & \multicolumn{2}{l}{ Protein pepsin-HCl } \\
\cline { 4 - 7 } & & & & & level ${ }^{1}$ & digestibility (\%) \\
Hydrolyzation & 654 & 14 & 552 & 73 & 350 & 63.3 \\
Final drying & 928 & 20 & 790 & 110 & 540 & 68.4 \\
\hline
\end{tabular}

1 Crude protein, digestible in pepsin- $\mathrm{HCl}$.

proteins, however, thermal treatments are largely used until now to convert feathers into feather meal based on the heat denaturation of the proteins.

By heating, the protein is losing its original proportions. It will result in disorganized state, without a change in amino acid composition. This is referred to as 'denaturation'. Keratin proteins are differentiated from other proteins by higher proportions of cystine among their constituent amino acids and by their greater resistance to heat denaturation. In general, denatured proteins offer a lower resistance to enzymatic digestion and show a decreased $N$ solubility (Kinsella, 1979). In feather processing, often the term 'hydrolysed' is used to indicate this change in the protein state. This term may be somewhat arbitrary because no actual hydrolyzation takes place in the short-time 'hydrolyzation' stage but, in fact, the proteins are denatured (Wohlbier, 1977). However, because the term 'hydrolyzation' is currently used, we will use this term also to indicate the change in the protein state.

A major difference in amino acid composition between raw and processed FM is a reduction in cystine concentrations and some variability in the content of other amino acids after treatment (Papadopoulos et al., 1986). Feather proteins exhibit high levels of cystine among its constituent proteins. When the cystine (disulfide) cross-link is broken, cystine will be released. This is partially converted into lanthionine, ornithine or other S containing compounds (Papadopoulos, 1984).

\section{Protein damage}

Protein damage, caused by intensive heat treatment, in general, calls for nutritional evaluation of processed feedstuffs. Protein quality, for example, is affected by the conditions applied in certain methods of processing. Factors affecting the nutritional availability seem to occur more markedly at higher temperatures. In this way, there may be differences in the protein quality of particular raw materials processed in either high temperature, short time (HTST-type) or medium temperature, medium time (MTMT-type) designed processing units.

Overheating feathers results in nitrogen loss and formation of gummy material. In general, overprocessing may be destructive to essential amino acids or will cause racimization of amino acids to the $\mathrm{D}$-form (de Wet, 1982). The re-establishment of cross-linking between amino acids has also been described (Bender, 1984). Feathers that have been underheated do not grind well, have low bulk density and are less digestible (Davis et al., 1961). 


\section{Processing methods}

Various methods and apparatus for conversion of feathers are used for the ultimate preparation of the desired final FM (Draper, 1944; Binkley \& Vasak, 1951; Sullivan \& Stephenson, 1957; Naber et al., 1961). These methods may be grouped according to the processing variables used such as pressure (temperature), moisture content, residence time and the possible use of shear and agitation. Those variables are causing differences in the protein quality of the final FM (Retrum, 1981).

Processing is based on exposing the feathers to elevated temperatures with saturated vapours. The most known process, greatly used, is generally referred to as dry rendering (batch) cooking. It can provide a rational approach to the bulk treatment of slaughtery wastes.

The stages that are mostly undertaken in processing of feathers are shown in Figure 1 and include:

- Confining raw feathers in a pressure chamber.

- Applying pressure and heat to this material to hydrolyse it with or without the use of steam or agitation; pre-drying.

- Final drying of the hydrolized product.

\section{Stages of processing and equipment}

Feathers are directly plucked from birds in the slaughterhouse and washed into a sluiceway employing water as a carrier to transport the feathers from the slaughtery house directly to the rendering processing plant. The feathers are then tumbled through a rendering screen to remove the bulk of the sluiceway water. Actual processing of feathers of FM consist of three main processes, carried out in two steps:

- hydrolization/sterilization of raw feathers

- drying the hydrolized feathers.

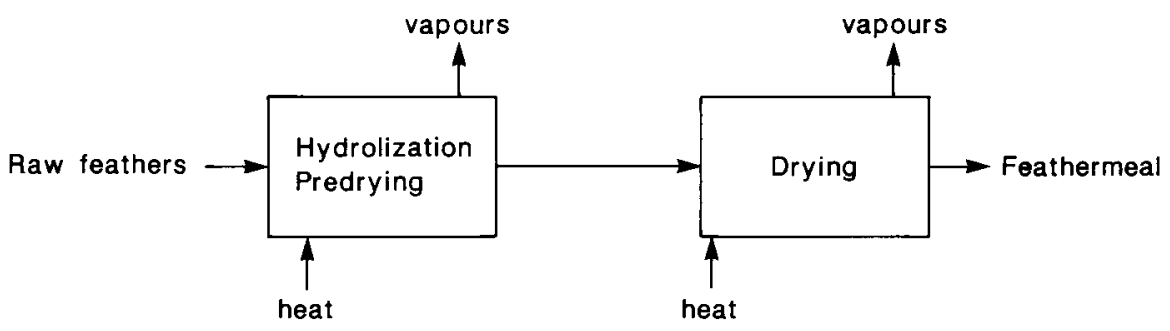

Raw materials

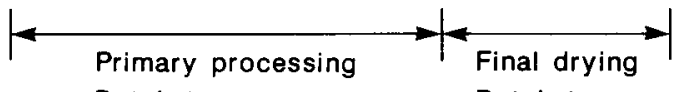

Final product

$$
\begin{array}{ll}
\text { - Batch type } & \text { - Batch type } \\
\text { - Continuous type } & \text { - Continuous type }
\end{array}
$$

Fig. 1. Stages in feather meal processing. 
Hydrolyzation is required to provide keratin protein denaturation in such a way that the naturally non-digestible proteins are converted into digestible proteins.

Sterilization of animal products including feathers is required by law and has been designed to assure processing conditions which guarantee the final product being free from pathogenic bacteria.

Drying is finaly used to achieve a moisture level of approximately $4 \%$ to $10 \%$ to facilate storage, handling and desired final quality.

\section{Hydrolization/sterilization stage}

Feather hydrolyzation can be realized by two distinguished types of processing, based on the temperature/time relationship of the heating treatment. These are:

- batch type indirect thermal processing

- continuous processing i.e. indirect thermal processing (steam heating) or mechanical/thermal processing (extrusion).

Both methods employ similar process conditions, i.e. feathers at high moisture level (appr. 60-70 \%) are hydrolyzed with steam at about 207 to $690 \mathrm{kPa}$ for about 30 to 6 minutes, respectively, and a subsequent first stage of thermal drying to about $50 \%$ moisture level. In commercial practice, the processing conditions vary to a large extent among processors. These conditions are influenced by the used apparatus, working schedules and individual opinions of the operator.

For the batch type of operation, the apparatus includes dry-rendering cookers with capacities of between 2 and $15 \mathrm{t}$ load. The cookers are horizontal cylindrical vessels with horizontal shaft-agitators and have a loading dome on the top and a front opening for discharge (Figure 2). After loading the cooker, the heat for the rendering process is provided by steam in a jacketed shell or in both the shell and the shaft-agitator. The cookers are generally designed for steam pressures of 414 to $850 \mathrm{kPa}$ and for operating at an internal pressure of about 207 to $350 \mathrm{kPa}$. The processing time for hydrolyzation is one to two hours from the time the cooker is closed until it is opened to discharge.

For sterilization, the raw material has to be heated under minimal conditions specified by law. These include a temperature of $133{ }^{\circ} \mathrm{C}$ for at least 20 minutes and an internal pressure of $300 \mathrm{kPa}$ (Tegge, 1977). These processing conditions comply with strict laws in various countries. The critical point for hydrolization appears the maintenance of the entire charge at the equivalent of $207 \mathrm{kPa}$ for at least 30 minutes (Davis, 1961).

Sterilization and hydrolyzation take place simultaneously because for hydrolization also temperature, internal pressure and time is needed. Consequently, the processing conditions for sterilization are convenient for protein denaturation. When pressure has been built up the hydrolysis may take place and afterwards, pressure can be released and the content can be dried.

Water removal by screw-pressing may result in a lower and more uniform moisture level on the material of approximately 50-59\% depending on the type of presses. Also, a better utilization of the vessels for the hydrolyzing stage is achieved as no pre-drying of the product is required. 

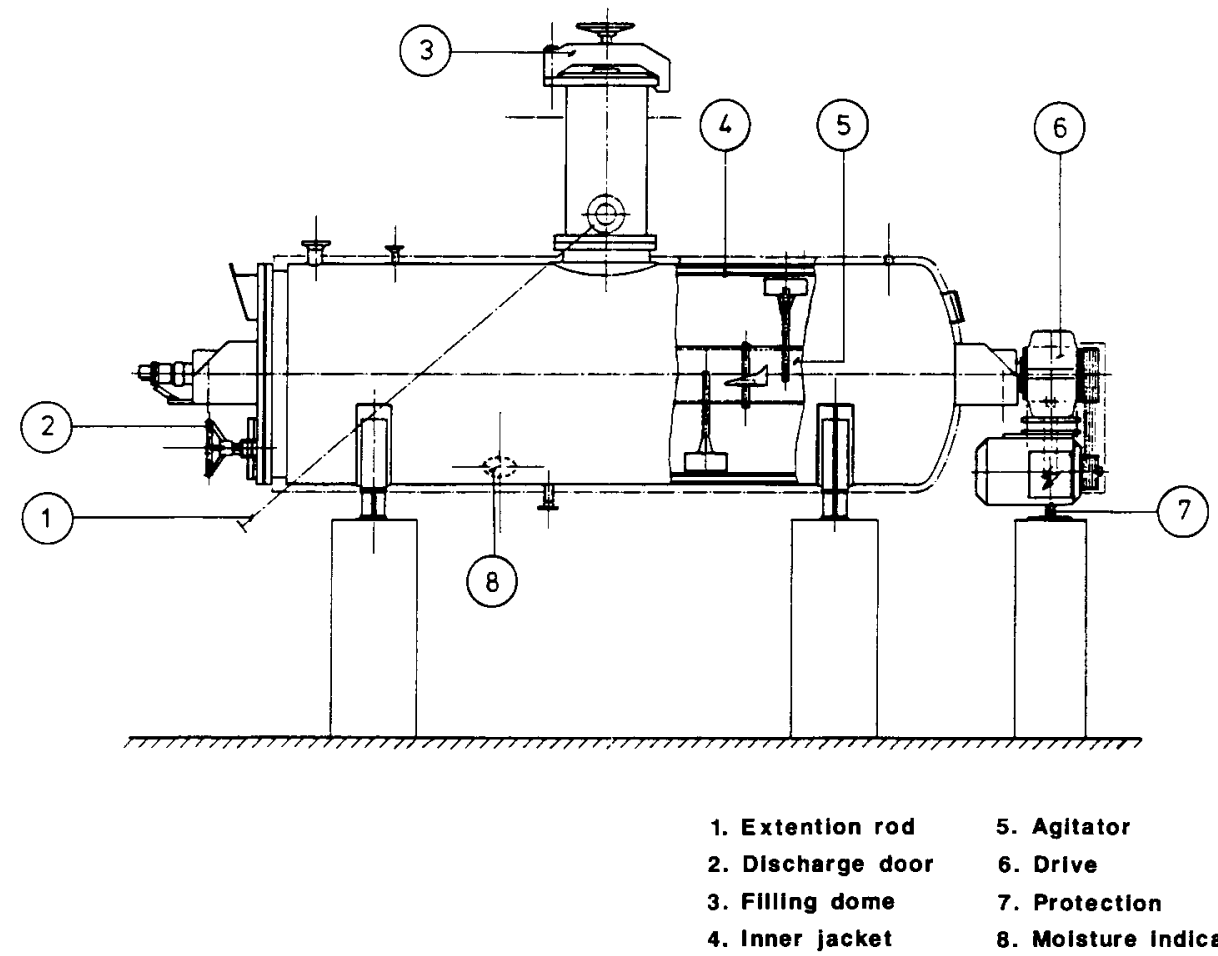

5. Agitator

6. Drive

7. Protection

8. Molsture Indicator

Fig. 2. A typical dry rendering cooker-drier (Stork Duke BV).

The continuous method is an extension of the batch-type method and the following steps are used:

- The feathers are hydrolyzed/sterilized at high moisture content (60-80\%) within the continuous operating pressurized vessel. Pressure is used of about 483 to 690 $\mathrm{kPa}$.

- A short residence time which can be adjusted (15 to 6 minutes; giving reduced heat exposure and reduced steam consumption). This system is operated continuously through intake and outlet sluiceways.

- Additional continuous drying (disc drier) to the required final moisture level.

In addition to the use of pressurized vessels, extrusion cooking is a further method for continuous hydrolization of feathers.

Extrusion includes the dewatering of raw feathers which are passed through a screw press where the natural moisture level is reduced to about 40-50 percent. The dewatered feathers are than subjected to the extrusion process in a HTST-designed (high temperature/short time) unit to homogenise, cook, dehydrate and sterilize the product. The extruder is equipped with a variety of worms within the barrel which transport the feathers along the barrel to the die outlet. The extruder uses the heat 
generated from the screw friction along with pressure and eventually steaminjection in processing the product. The water is maintained in its liquid phase to hydrolize the keratin proteins. At the outlet die, reaching normal pressure, some water is evaporated immediately (flashing).

Typical processing conditions in the extruder are 20-30 seconds residence time, at least $3500 \mathrm{kPa}$ pressure, and a temperature of $100-160^{\circ} \mathrm{C}$, respectively, to give $30 \%-35 \%$ moisture content in the final product (Williams et al., 1979). After extrusion, feathers have to be thermally (indirectly) dried.

Only recently, alternatives for the extrusion of feathers have been developed using enzyme premix additions and/or adding dry ingredients to feathers prior to extrusion (Davies, 1989). According to Davies (1989) the conventional processing of feathers by pressure and steam may range from 50-80 \%. A much higher (pepsin) digestibility (over $90 \%$ ) can be consistently achieved utilizing a new technology.

\section{Drying stage}

The method of drying is an economical way of processing in terms of moisture level control. Normally it does not influence the quality of the feather meal protein although short time drying in air-heated driers may give some better results. Drying of the hydrolyzed product can be carried out in the same cooker (batch type processing) by indirect steam heating or indirect fired driers.

Furthermore, continuous processing can be carried out by indirect thermal drying (disc drier) or direct thermal drying (flash dryer).

The efficiency of drying depends on the temperature/time relationship established in the several apparatus. For example, drying in a cooker/drier requires more time in comparison with the time needed for drying in a disc drier or flash drier. Typical data on the production of FM from raw feathers are given in Table 2.

Based on a higher heating surface area of the apparatus and in relation with a higher temperature the latter types of drier require a shorter processing time for drying. An alternative to the final drying stage is feather dewatering. Hydrolized

Table 2. Typical production data for a feather meal processing line ${ }^{1}$.

\begin{tabular}{lll}
\hline Parameter & Unit & Value \\
Quantity of feathers/day & $\mathrm{kg}$ & 40000 \\
Time/load batch cooker & hour & 2.5 \\
Moisture level after batch cooker & $\%$ h & $45-50$ \\
Time/load flash drier & $\mathrm{h} \mathrm{min}-1$ & $1 / 45$ \\
Moisture level after flash drier & $\%$ & $2-4$ \\
Cycli/day & & 8 \\
Capacity raw feathers (70 \% moisture) & $\mathrm{kg} \mathrm{h}^{-1}$ & 2500 \\
Feather meal (4 \% moisture) & $\mathrm{kg} \mathrm{h}^{-1}$ & 800 \\
\hline
\end{tabular}

1 Processing line: storage bin - batch cooker - receiving hopper - screw conveyor - flash drier.

2 Time for loading, discharge and some drying included.

3 For $8 \%$ final moisture content, time $/$ load $=1 \mathrm{~h} / 20 \mathrm{~min}$. 
feather products are very wet and with moisture levels up to $70 \%$. Dewatering, prior to drying, can be successfully done with both a single or twin screw press.

\section{Nutritional evaluation}

\section{In vitro}

Conversion of feathers to FM involves physical and chemical changes. A principle chemical change is the loss of cystine and the appearance of lanthionine and also the increased susceptibility to enzymatic hydrolysis and in vivo digestibility. Loss of cystine probably occurs through desulfurization reactions that may lead to unstable residues of dehydroalanine. These condense subsequently with cystine to form lanthionine or with the $\epsilon$-aminogroup of lysine to form lysinoalanine as a result of thermal degradation (Bjarnason \& Carpenter, 1970).

The definition to the standard feather meal has been reported by the Association of American Feed Control Officials as follows: 'Hydrolysed poultry feathers is the product resulting from the treatment under pressure of clean, undecomposed feathers from slaughtered poultry, free of additives and/or accelerators. Not less than $70 \%$ of its crude protein content shall consist of digestible protein'.

In this definition the processing method has been related to a quality parameter of the final product, being in vitro protein digestibility (IVPD) by pepsin- $\mathrm{HCl}$ (Gehrt et al., 1955; AOAC, 1976). This method has been described as an accepted means to measure the relative digestibility of proteins for animal feed ingredients. Standardization of the pepsin-HCl-test proved to be difficult due to differences in the purity and in the activity of pepsin concentrations and differences in levels of pepsin- $\mathrm{HCl}$ solutions. The published data on IVPD, therefore, differ widely. Levels of IVPD are reported to vary between 45 and $95 \%$ (Wohlbier, 1977; Papadopoulos, 1984). Therefore, this must be taken into account in relation with the qualifications on IVPD of feather meal for livestock feeding purposes.

On the other hand it is interesting to examine these process and processing variables which are critical to this observed large variation.

The effects of processing time (at $207 \mathrm{kPa}$ pressure) on both protein digestion (pepsin-HCl) and IVPD $\times \%$ Meth + Cyst-retained (Retrum, 1981) are shown in Figure 3. It is clear that two reactions take place at the same time.

As shown by Papadopoulos et al. (1986) the extent of variations found in literature for in vitro digestibility of protein due to processing are similar. However, there exists an inverse relationship between IVPD and the degradation of some essential amino acids, in particular lysine, cystine and histidine.

Different processing variables such as pressure, time and moisture will influence the in vitro digestibility of FM proteins and amino acids. Davis et al. (1961; Table 3) reported that to obtain appr. $70 \%$ pepsin- $\mathrm{HCl}$ digestibility in relation with pressure at 207, 414 and $621 \mathrm{kPa}$ large differences existed in hydrolyzation times. They also related pepsin- $\mathrm{HCl}$ digestibility to hydrolyzation time at a pressure of $207 \mathrm{kPa}$. At this pressure, digestibility increases rapidly until a level of about $70 \%$ but thereafter it increases only slowly. This may be of importance for the temperature/time 


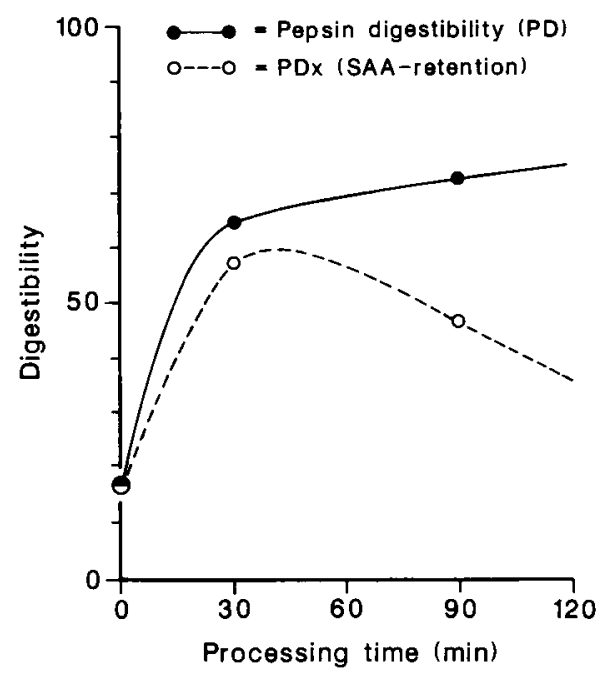

Fig. 3. Effects of processing time on protein pepsin- $\mathrm{HCl}$ digestibility and on retention of sulfer amino acids (Davis et al., 1961).

pattern used in the subsequent processing steps, in batch type treatments. In this type of processing, heating time to the required pressure level, and sterilization/hydrolyzation time can be altered to optimize the protein quality of the final FM. The processing time depends to a large extent on the time that is required to reach and to reduce pressure. The built up of pressure in a quickly way is important because only little hydrolyzation takes place at pressure values lower than $138 \mathrm{kPa}$. Therefore, alternatives to standard processing (Figure 4a) can be developed (Figure $4 b)$ which may improve protein quality.

In evaluating FM protein quality by the levels of essential amino acids, it was shown that the highest levels of lysine are obtained at different combinations for time and pressure. Hydrolyzation time and pressure for this objective were 30 $\mathrm{min} / 207 \mathrm{kPa}$ (Davis et al., 1961), $60 \mathrm{~min} / 345 \mathrm{kPa}$ (Morris \& Balloun, 1973) and $30 \mathrm{~min} / 436 \mathrm{kPa}$ (Papadopoulos, 1984), respectively. In Table 4 protein quality parameters are presented depending on the hydrolyzation conditions. These results

Table 3. Time required to achieve $75 \%$ digestibility (pepsin $\mathrm{HCl}$ ) using direct steam injection without agitation (Davis et al., 1961).

\begin{tabular}{llc}
\hline Temperature $\left({ }^{\circ} \mathrm{C}\right)$ & Pressure $(\mathrm{kPa})$ & Processing time $(\mathrm{min})$ \\
166 & 621 & 7 \\
153 & 414 & 20 \\
134 & 207 & 90 \\
\hline
\end{tabular}




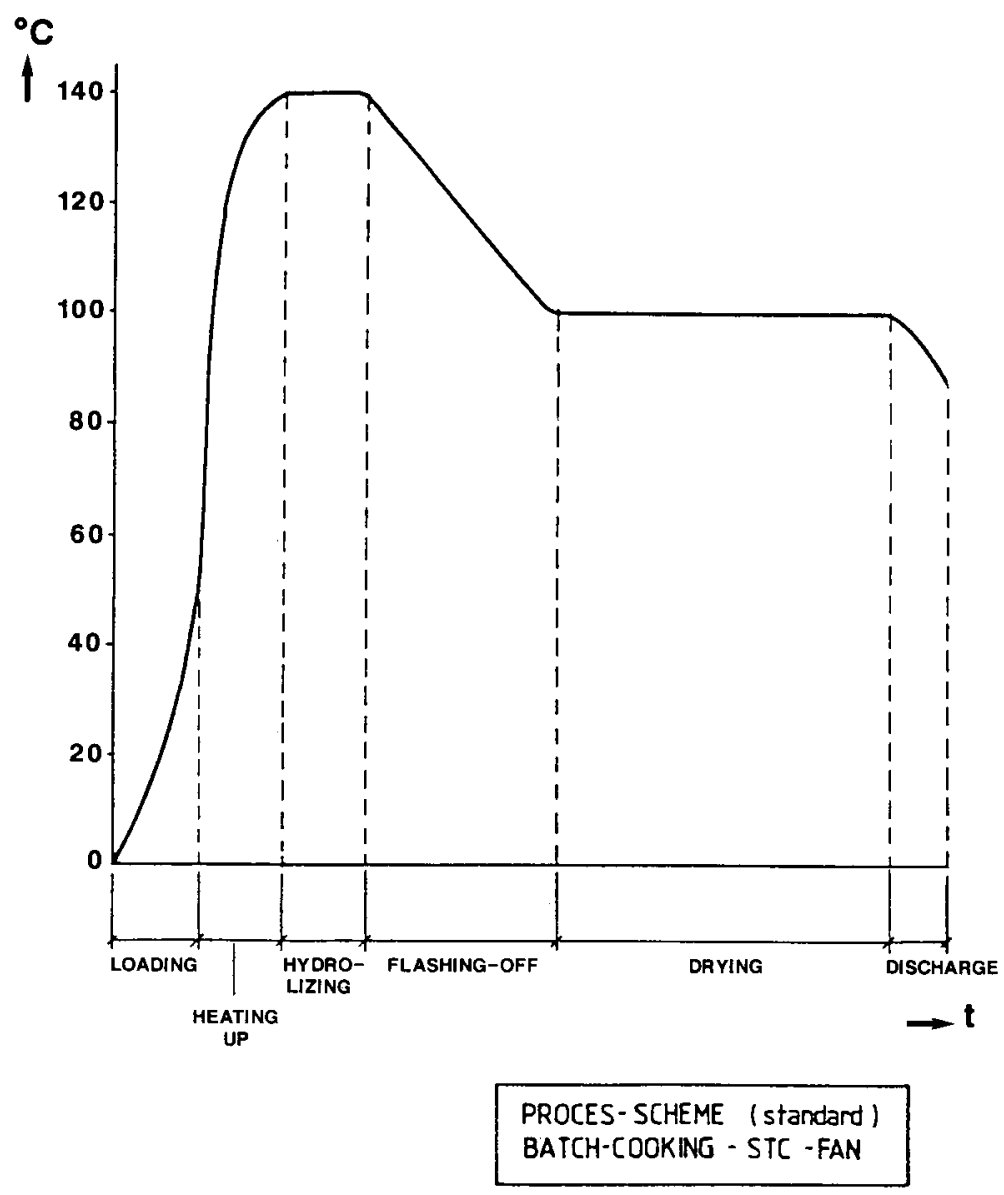

Fig. 4a. Standard temperature/time relationships for the hydrolization/drying stage in feather processing (batch cooking) (Stork Duke BV).

indicate that there is obviously no general agreement at this point. However, it should be noted that raw feathers may vary in their composition and that the processing equipment used by the authors was not identical. A clear description, therefore, of the used equipment and processing variables are important to the evaluation of feather meal quality parameters.

Changes in the composition of FM due to different moisture contents during hydrolyzation have been reported to result in a lineair effect on the $\mathrm{S}$ containing amino acids, cystine and methionine (Papadopoulos et al., 1986). These effects were established with moisture levels ranging from $50-70 \%$ and hydrolyzation times ranging from 30-70 minutes at a fixed pressure of $436 \mathrm{kPa}$. Under these conditions, most of the essential and all of the non-essential amino acids showed lower levels in the more highly moistened meals after treatment. 


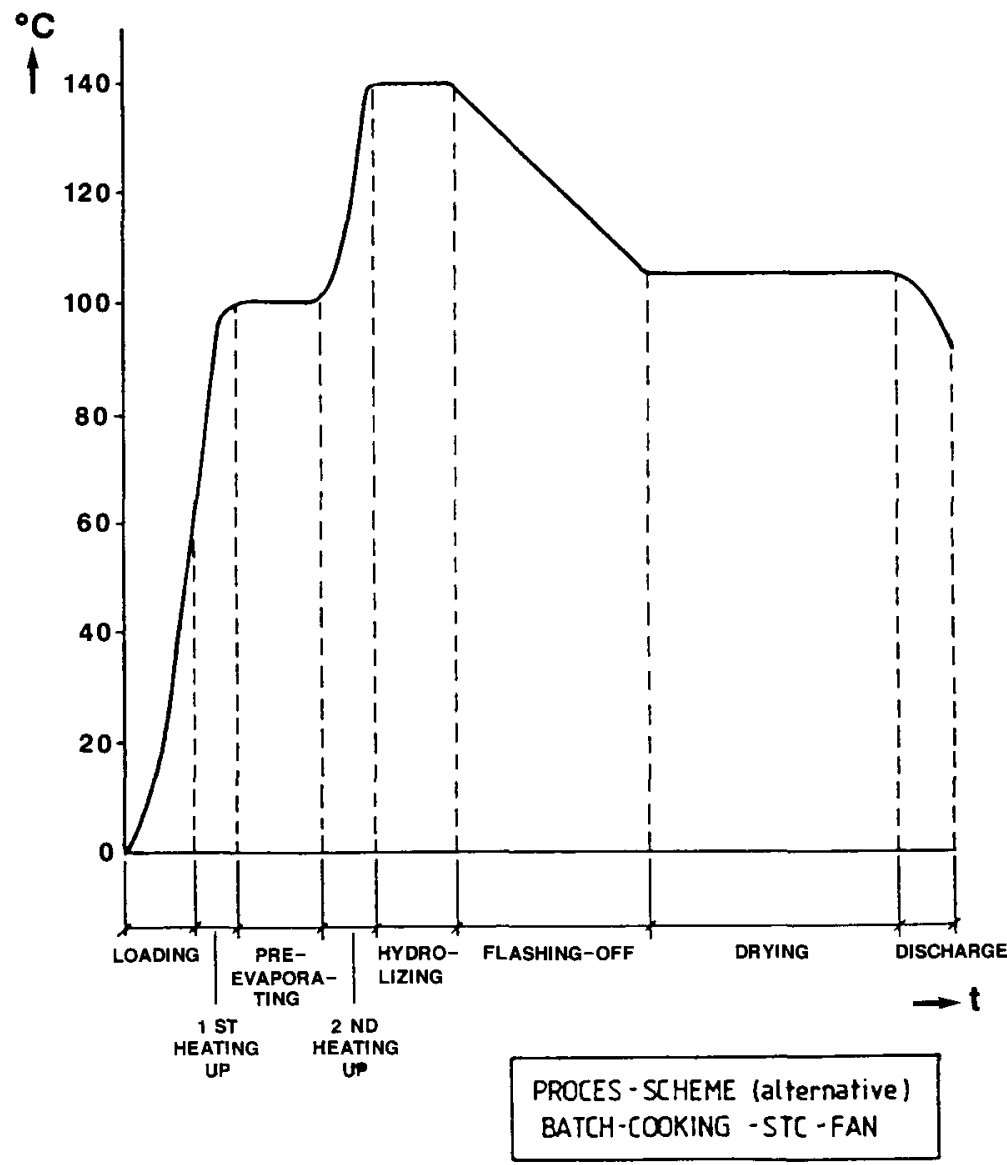

Fig. 4b. Alternative process scheme for the hydrolyzation/drying stage in feather processing (batch cooking) (Stork Duke BV).

In vivo

Feather meal (FM) is of value in replacing limited quantities of various protein feedstuffs in practical rations for animals (Cabel et al., 1987). The value of FM depends largely on its protein quality, which is strongly influenced by processing methods.

Bioassays, abbreviated biological methods and chemical methods need to be used for measurement of protein quality (Bender, 1984). Only few recent experiments have been carried out on the digestibility of nutrients, especially amino acids in processed feathers. The digestibility of protein from FM by chicks has been reported to range between $55 \%$ (Bielorai et al., 1982; Neumark et al., 1982) and $76 \%$ (El Boushy \& Roodbeen, 1984). The FM composition and FM digestibility coefficients for pigs of organic matter and protein are shown in Table 5. For protein, digestibility coefficients range between 77 and 87 percent. 


\section{A. F. B. VAN DER POEL AND A. R. EL BOUSHY}

Table 4. Effect of hydrolyzation conditions on FM in vitro protein digestibility (IVPD) and levels of cystine and lanthionine. 1

Batch I

\begin{tabular}{|c|c|c|c|c|}
\hline \multicolumn{2}{|c|}{ Conditions } & \multicolumn{3}{|c|}{ Quality parameters } \\
\hline \multirow{2}{*}{$\begin{array}{l}\text { pressure } \\
(\mathrm{kPa})\end{array}$} & agitation & \multirow{2}{*}{$\begin{array}{l}\text { IVPD }^{2} \\
(\%)\end{array}$} & \multirow{2}{*}{$\begin{array}{l}\text { cystine } \\
(\%)\end{array}$} & \multirow{2}{*}{$\begin{array}{l}\text { lanthionine } \\
(\%)\end{array}$} \\
\hline & yes no & & & \\
\hline
\end{tabular}

Unprocessed

Processed:

for $20 \mathrm{~min}$

for $30 \mathrm{~min}$

for $40 \mathrm{~min}$

Batch II

Unprocessed

Processed:

for $30 \mathrm{~min}$

for $50 \mathrm{~min}$

for $70 \mathrm{~min}$

$\begin{array}{lll} & & 16 \\ 414 & * & 72 \\ 207 & * & 64 \\ 207 & * & 71\end{array}$

16

72

64

71

-
94
90
94

$\begin{array}{ll}8.2 & - \\ 5.8 & 1.7 \\ 7.1 & 1.3 \\ 5.1 & 2.1\end{array}$

I Data from Davis et al. (1961) and Papadopoulos (1984).

2 In vitro pepsin $\mathrm{HCl}$ digestibility.

The need for relatively high dietary protein levels during the starter and/or finisher diets for broilers justifies the consideration of using unconventional and inexpensive protein sources like FM. In addition to the protein contribution of FM, it has been also reported that short term feeding of FM may aid in reducing abdominal fat deposition in broilers (Bielorai et al., 1983).

Table 5. Feather meal composition ( $\mathrm{g} \mathrm{kg}^{-1} \mathrm{DM}$ ) and faecal digestibility coefficients (\%) of organic matter and crude protein for pigs (mean $\pm \mathrm{SD}$ ).

\begin{tabular}{|c|c|c|c|c|c|}
\hline \multicolumn{3}{|c|}{ Feather meal composition } & \multicolumn{2}{|c|}{ Digestibility coefficients } & \multirow[t]{2}{*}{ Reference } \\
\hline dry matter & organic matter & crude protein & organic matter & crude protein & \\
\hline $\begin{array}{l}90.9 \\
(1.7)\end{array}$ & $\begin{array}{l}97.3 \\
(0.7)\end{array}$ & $\begin{array}{l}94.3 \\
(1.1)\end{array}$ & $\begin{array}{l}81.4 \\
(6.2)\end{array}$ & $\begin{array}{l}85.7 \\
(2.9)\end{array}$ & $\begin{array}{l}\text { Sebek (pers. } \\
\text { comm.) } \\
(n=6)\end{array}$ \\
\hline 90.0 & - & 83.7 & - & 78.8 & $\begin{array}{l}\text { Houben, } 1986 \\
(n=1)\end{array}$ \\
\hline 90.0 & - & 83.7 & - & 77.3 & $\begin{array}{l}\text { Houben, } 1986 \\
(n=1)\end{array}$ \\
\hline
\end{tabular}




\section{Discussion}

The treatments described here include a variety of processes and apparatus for converting feathers into sterilized and digestible products. For example, pressing feathers to reduce moisture content prior to the hydrolyzation stage has also been described (Williams et al., 1979) and is common practice in some Dutch rendering industries.

Processes for effecting hydrolyzation of materials, including feathers, normally incorporate structures that provide for the batch handling of such materials as reported by Retrum (1981). The batch type of operation requires a substantial amount of time. This is needed for loading the cookers and for the built up of heat and consequent pressure.

The indirect application of heat in the batch process gives the renderer flexibility in the processing variables being time, pressure, temperature etc., compared with the continuous methods. The continuous method has a fixed processing time and pressure.

The processing time for hydrolyzation depends on pressure (temperature). It has been reported that water at $135^{\circ} \mathrm{C}$ under $207 \mathrm{kPa}$ pressure can hydrolyze keratin within 30 minutes to the extent of $70 \%$ IVPD (Williams et al., 1979). Under atmospheric conditions at $100{ }^{\circ} \mathrm{C}$ this cannot be done even within longer processing times.

The law requirements for sterilization are setting minimum standards for the processing conditions of feathers. This means that conditions for hydrolyzation become critical to those for sterilization, especially when no actual data are known for an optimal time/temperature relationship for hydrolyzation. The changes during hydrolyzation have been reported to be most rapid during the first 30 minutes of treatment at $207 \mathrm{kPa}$ of steam pressure for batch type of processing (Davis et al., 1961). Also, breakage of disulfide cross-linkages is rapid during this period, resulting in the conversion of cystine to lanthionine.

Few studies have been reported on the effect of processing variables on nitrogen and amino acid digestibility, determined by chemical/enzymatical or bioassays (Papadopoulos, 1986; El Boushy et al., 1990). The quality of the final FM in practice is based upon protein digestibility in vitro by pepsin- $\mathrm{HCl}$ test. This characteristic of FM as a prediction of nutritional value is particulary affected by the used method of hydrolyzation. For the batch-type processing method values for the digestibility of approximately $70 \%$ have been found, although reported differences upon treatments are very large. For feathers, processed with the continuous method, these values have not been found in literature. Likewise, the pepsin- $\mathrm{HCl}$ digestibility of feathers, processed by the continuous method, has still to be evaluated as a criterium for the protein nutritional value. Also, due to the more HTST-designed process, it has not yet been clearified, whether reversibility of the protein denaturation may follow breakdown of cross-links in the protein molecule.

Apart from the lack of information on pepsin- $\mathrm{HCl}$ digestibility as influenced by processing methods, it is still the question whether this chemical/enzymatical estimation is adequate to evaluate FM protein quality. Total amino acids or soluble 
nitrogen as an indicator are reported to be not adequate in this (Papadopoulos, 1984). Therefore, more specific in vitro digestibility measurements on the individual amino acids have to be developed which are in good agreement with in vivo digestibility values. Also, the level of lanthionine present in FM may be a reasonable indicator of treatment since the amino acid digestibility values of processed FM are inversely proportional to the lanthionine contents (Papadopoulos, 1984). For a quick estimate of protein quality, the bulk density of processed feather meal has to be further investigated as a quality parameter. A close relationship was observed between bulk density and pepsin- $\mathrm{HCl}$ digestibility in the initial studies of Davis et al. (1961).

Suggestions for further research to improve FM quality as a result from technological treatments, may include:

1. Systematic studies on the influence of processing (time/pressure and moisture content), particularly in the hydrolyzation stage of processing, on FM proteinamino acid quality.

2. In vivo studies on the availability of essential amino acids and/or protein digestibility, if possible on the ileal level (digestion at the terminal ileum) of digestion for poultry and pigs.

3. Establishing quality control parameters (bulk density, lanthionine level, in vitro protein digestibility) based on correlations of in vitro and in vivo studies.

4. Search for new applications for feather processing, e.g. the co-extrusion of FM with dry ingredients as well as the subsequent use of enzymes and extrusion.

\section{Acknowledgement}

The authors thank Stork Duke BV for providing some of the figures.

\section{References}

Association of American Feed Control Officials, 1960. Official publication, Lexington, KY, 189 pp.

Bender, A. E., 1984. Protein quality. Determination and usefulness. Proceedings MOCCA, Vol. II, p. 83-90.

Bielorai, R., Z. Horduf, B. Iosif \& E. Alumot, 1983. Apparent amino acid absorption from feather meal by chicks. British Journal of Nutrition 49: 395-399.

Bielorai, R., B. Iosif, H. Neumark \& E. Alumot, 1982. Low nutritional value of feather-meal protein for chicks. Journal of Nutrition 112: 249-254.

Binkley, C. H. \& O. R. Vasak, 1950. Production of a friable meal produced from feathers. US Bureau Agriculture and Industrial Chemical Circular Bulletin, AIC-274, 5 pp.

Bjarnason, J. \& K. J. Carpenter, 1970. Mechanism of heat damage in proteins. 2. Chemical changes in pure proteins. British Journal of Nutrition 24: 313-329.

Cabel, M. C., T. L. Goodwin \& P. W. Waldroup, 1987. Reduction in abdominal fat content of broiler chickens by the addition of feathermeal to finisher diets. Poultry Science 66: 1644-1651.

Davis, J. G., E. P. Mecchi \& H. Lineweaver, 1961. Processing of poultry by-products and their utilization in feeds. 1. Processing of poultry by-products. USDA, ARS, Utilization Research Report No $3,40 \mathrm{pp}$.

Davies, J., 1989. Low cost extrusion solves wet waste problems. Poultry-Misset 5, 5: 27-29.

Draper, C. I., 1944. The nutritive value of corn oil metal and feather proteins. Iowa Agriculture Experimental Station Research Bulletin 326: 163-184. 
El Boushy, A. E. \& A. E. Roodbeen, 1984. Amino acid availability in dry poultry waste in comparison with relevant feedstuffs. Poultry Science 63: 583-585.

El Boushy, A. R., A. F. B. van der Poel \& O. Walraven, 1990. Feather meal - A biological waste: its processing and utilization as a feedstuff for poultry. Biological Waste 32: 39-74.

Gehrt, A. J., M. J. Caldwell \& W. P. Elmslie, 1955. Chemical method for measuring relative digestibility of animal protein feedstuffs. Journal of Agriculture and Food Chemistry 3: 159-162.

Houben, M., 1986. The digestibility of hydrolysed feather meal determined by classical and Mobile Nylon Bag digestibility experiments with swine (In Dutch). Department of Animal Nutrition, Wageningen Agricultural University, Wageningen, Netherlands, $35 \mathrm{pp}$.

Kinsella, J. E., 1979. Functional properties of soy proteins. Journal of the American Oil Chemists' Society 56: 242-258.

McCasland, W. E. \& L. R. Richardson, 1966. Methods for determining the nutritive value of feather meals. Poultry Science 45: 1231-1236.

Morris, W. C. \& S. L. Balloun, 1973. Evaluation of fine differently processed feather meals by nitrogen retention, net protein values, xanthine dehydrogenase activity and chemical analysis. Poultry Science 52: 1075-1084.

Naber, E. C., S. P. Touchburn, B. D. Barnett \& C. L. Morgan, 1961. Effect of processing methods and amino acid supplementation on dietary utilization of feather meal protein by chicks. Poultry Science 40: 1234-1245.

Neumark, H., R. Bielorai \& B. Iosif, 1982. Magnesium ferrite as a marker in absorbtion trials with chicks. Journal of Nutrition 112: $387-390$.

Papadopoulos, M. C., 1984. Feather meal: evaluation of the effect of processing conditions by chemical and chick assay. Doctoral Thesis, Wageningen Agricultural University, Wageningen, Netherlands, 139 pp.

Papadopoulos, M. C., 1986. The effect of enzymatic treatment on amino acid content and nitrogen characteristics of feather meal. Animal Feed Science and Technology 16: 151-156.

Papadopoulos, M. C., A. E. El Boushy \& A. E. Roodbeen, 1985. The effect of varying autoclaving conditions and added sodium hydroxide on amino acid content and nitrogen characteristics of feathermeal. Journal of the Science of Food and Agriculture 36: 1219-1226.

Papadopoulos, M. C., A. R. El Boushy, A. E. Roodbeen \& E. H. Ketelaars, 1986. Effects of processing time and moisture content on amino acid composition and nitrogen characteristics of feather meal. Animal Feed Science and Technology 14: 279-290.

Rasmussen, O. G., R. Hansen, N. J. Jacobs \& O. H. M. Wilder, 1964. Dry heat resistance of Salmonellae in rendered animal by-products. Poultry Science 43: 1151-1157.

Retrum, R., 1981. Apparatus for hydrolyzing keratinaceous material. US Patent No 4, $286,884$.

Sullivan, T. W. \& E. L. Stephenson, 1957. Effect of processing methods on the utilization of hydrolized poultry feathers by growing chicks. Poultry Science 36: 361-365.

Tegge, E., 1977. Tierkorperbeseitigungsgesetz. Neue Kommunale Schriften 35, Bundesministerium fur Ernahrung, Landwirtschaft und Forsten. Deutscher Gemeindeverlag, Verlag W. Kohlhammer, 77, $116 \mathrm{pp}$.

Wet, P. J. de, 1982. Effect of processing of nutritional value of feeds: protein. In: M. Rechcigl Jr. (Ed.) Handbook on nutritional value of processed food. Vol. II. Animal Feedstuffs, p. 321-341. CRC Series in Nutrition and Food. CRC Press Inc., Boca Raton, Florida, USA.

Williams, M. A., R. E. Horn \& C. Bronikowski, 1979. Process for hydrolyzing proteinaceous derivates of the skin. US Patent No 4, 151, 306.

Wohlbier, W., 1977. Keratinhaltige Futtermittel. In: M. Kling \& W. Wohlbier (Eds), Handelsfuttermittel Band I, p. 263-288. 